\title{
Welfare Beneficiary Community BUMDes Karya Dermawan Dusun Dalam Village
}

\author{
Muhammad Fauzi ${ }^{*}$, Asa'ari², Arzam ${ }^{3}$, Mursal $^{4}$, Zufriani' ${ }^{5}$, Aidil Novia 6 , Dafiar \\ Syarif 7
}

1, 4,7 Faculty of Islamic Economics and Business, State Islamic Institute of Kerinci, Indonesia

2,3,5 Faculty of Sharia, State Islamic Institute of Kerinci, Indonesia

${ }^{6}$ Faculty of Islamic Economics and Business, State Islamic University Imam Bonjol of Padang, Indonesia

\section{ART I C L E I N F O}

\section{Article history:}

Received July 17, 2021

Revised July 20, 2021

Accepted August 12, 2021

Available online August 25, 2021

Keywords:

Welfare, Beneficiary

Community, BUMDes, Dusun

Dalam Village

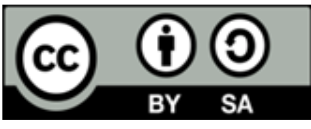

This is an open access article under the CC BY-SA license.

Copyright $($ C) 2021 by Author. Published by Universitas Pendidikan Ganesha.

\begin{abstract}
A B S T R A C T
Dusun Dalam Village Government established a Village-Owned Enterprise (BUMDes) Karya Dermawan is a policy utilization. The main pillar was established BUMDes Karya Dermawan in accordance with the mandate of the objectives whose activities were oriented to encourage the welfare of the village community. Therefore, this study was conducted aimed at looking at the welfare provided by BUMDes Karya Dermawan Dusun Dalam village especially to the beneficiary community and compare the level of welfare before and after BUMDes Karya Dermawan was established. This study uses a descriptive quantitative approach, and data sourced from primary data by using Paired Sample t-Test as a data analysis tool. This study shows that BUMDes Karya Dermawan provides welfare to the beneficiary communities through businesses that have been established including Cooperatives; Alsintan; and Workshop, which is directly able to change or succeed in providing an increase in welfare for the beneficiary community after the establishment of BUMDes as evidenced by the results of the Paried Sample t-Test analysis. With this evidence of success, for all elements should give intensive attention; so that the development of BUMDes Karya Dermawan exists even more as a driver of community welfare. And also, integratedly invites and becomes a valuable lesson for existing villages to establish BUMDes or villages that already have BUMDes, but have not succeeded in providing a common thread for the welfare of their citizens.
\end{abstract}

\section{INTRODUCTION}

The idea (theories and concepts) of community welfare is usually defined as Economic Welfare, but some interpret it as Social Welfare. In Economic Welfare, say that every individual or society must like greater material needs (goods and services), with little mention of social science issues (Albert \& Hahnel, 2017; Hahnel, 2005; McCain, 2019). Meanwhile, Social Welfare deals with material (economic) and nonmaterial (social) aspects (Ife \& Tesoriero, 2008), with emphasis on efforts and actions carried out by the government or a social service institution, and/or as the goal of development activities to help meet the needs of individuals or communities (material and non-material) (Zastrow, 1996; Midgley, 1995; 1998; Midgley \& Hosaka, 2011). Thus, it can be seen that the big picture of the discussion of the two ideas and the concept of community welfare is not separated, because they both talk about achievement in meeting material and non-material needs. The achievement of these needs, can actually deliver Utility and Pleasure for life, and/or can support a better Quality of Life in the same social aspect to other fellow citizens.

In the modern context, the idea is still used to measure (indicator) the level of community welfare (Fahrudin, 2014), as at the national level, the Badan Pusat Statistik (BPS, 2015) offers 5 (five) classifications of indicators of community welfare in an area, including the level of family income; alignment of family expenditures for consumption and other needs;, education level;, family health condition; , and the condition of the family's residence along with the facilities and amenities it has. Furthermore, BKKBN (Badan Kependudukan Keluarga Berencana Nasional) divides community welfare into 3 (three) needs, namely Basic Needs, Social Physihcological Needs, and Development Needs. Based on these three needs, it was developed as a classification of prosperous family indicators into 5 (five)- stages including pre-prosperous 
family;, prosperous family 1 ;, prosperous family 2 ;, prosperous family 3 ; , and prosperous family 3 plus (Bappenas, 2010).

From a national perspective, the decisive line that is indispensable for realizing a prosperous village community (past-present) is the attention of the government, both at the central, provincial and district levels. (Suyanto \& Pudjianto, 2015), because their duties have been enshrined in the 1945 Constitution as implementers of welfare for all citizens (Syawie \& Sitepu, 2012). From there, if look at the journey of the government's attention to realizing a prosperous village community (past-now) it is designed by launching various forms of institutions, as now the trend of its existence is Village Owned Enterprises (BUMDes) (Budiono, 2015; Ridlwan, 2014; Winarti et al, 2020). BUMDes institutions have strong regulations. Among these regulations include Laws, Government Regulations, Ministerial Regulations, and can be further regulated in Regional Government Regulations, and in each village can also make village regulations regarding BUMDes, but still guided or referring to existing regulations, and can be adapted to the circumstances and characteristics of the village (Ridlwan, 2013).

The idea contained in the regulation that BUMDes is a village business institution managed by the community and village government in an effort to strengthen the village economy, was formed based on community needs and village potential. The economic potential of the village is developed into BUMDes business units, with the aim of obtaining economic benefits for the village and community (commercial and social); thus encouraging the improvement of the welfare of rural communities. The business units established by BUMDes are indicators of the creation of increased welfare for rural communities (Ikhwansyah, 2020), by providing and helping to increase income, basic necessities of life (basic needs), capital participation, employment opportunities for the community, and so on (Asmarianti, 2019; Cahyani et al, 2019; Caya \& Rahayu, 2019; Kirowati \& Setia, 2018; Kusumasari, 2018; Nugroho, 2015; Nurhasan \& Munawar, 2020; Prihatin et al, 2018; Tama, 2013). From the description above, it is clear how BUMDes provides welfare to the village communities. From here, too, a strong impression that becomes an urgent note in managing the business units established by BUMDes, must adhere to the existing principles including cooperative; , participatory;, emancipatory;, accountable;, sustainable;, and transparency; (PKDSP, 2007; Ridlwan, 2014; Zulkarnaen, 2016). If stick to these principles, justru can actually draw a common thread as an institution for improving the welfare of rural communities (Anggraeni, 2016; Melatyugra, 2020; Setyobakti, 2017).

The establishment of BUMDes Karya Dermawan, precisely in 2014, as stipulated through Dusun Dalam Village Regulation No. 1 of 2014 concerning the Establishment and Management of Village Owned Enterprises (BUMDes) Karya Dermawan. With the stipulation and issuance of this regulation, all forms of local wisdom, potential, and resources began to be built and run into BUMDes businesses including Cooperative, Agricultural Machinery Equipment Services (Alsintan), Distribution of Production Facilities (Penyaluran Sarana Produksi), Waste Banks (Bank Sampah), and Workshops (Perbengkelan). From there, this research aims to see how BUMDes Karya Dermawan Dusun Dalam provides welfare to the beneficiary community. By knowing the provision of welfare, it will be seen how the existence of BUMDes as an institution that encourages welfare community. And also compare the welfare level of beneficiary before and after the establishment of BUMDes Karya Dermawan.

\section{METHODS}

The research that took place at BUMDes Karya Dermawan Dusun Dalam village is a field research and quantitative descriptive as an approach method that one of the objectives is to test research hypothesis (Yusuf, 2005). From here the research hypothesis reads; $\mathrm{H} 0=$ There is no difference in the welfare of the beneficiary community before and after the establishment of BUMDes. Ha= There are differences in the welfare of the beneficiary communities before and after the establishment of BUMDes. The beneficiary community of BUMDes Karya Dermawan consist of pre-prosperous families with prosperous families 1 (one), as many as 150 people as the population in this study. By looking at a large population, the researcher limits it to people who represent the population or often referred to as the sample, which is calculated by the "Slovin" method. From the calculation results obtained a sample of 60 people (Sujarweni, 2015).

Research data sourced from primary data in the form of a questionnaire containing questions about welfare among others Monthly Income, Basic Needs, Asset Ownership, Household Facilities and Infrastructure, Access to Health Facilities, Education; (as are presented in Table 1). Furthermore, interviews are included to strengthen so that the results obtained are clear (Yusuf, 2005).

The primary data source (questionnaire), it was processed and analyzed using the Paried Sample $\mathrm{t}$-Test analysis tool, which is often termed a different test before and after on correlated or paired samples (Sujarweni, 2015); Meanwhile, the basis for making decisions on the Paried Sample t-Test analysis, among others; first, if the significant value of 2 tailed $<0.05$ then Ha is accepted and H0 is rejected, meaning that 
there are differences in the welfare of the beneficiary community before and after the establishment of BUMDes. Second, if the significant value of 2 tailed $>0.05$, then $\mathrm{HO}$ is accepted and Ha is rejected, meaning that there are differences in the welfare of the beneficiary communities before and after the establishment of BUMDes. Further steps for data processing assisted by the SPSS program (Nuryadi et al, 2017).

Tabel 1. Instrument Grid

\begin{tabular}{cl}
\hline Indicator & \multicolumn{1}{c}{ Sub Indicator } \\
\hline & $>$ IDR. 250.000 IDR. 400.000 \\
Monthly Income & $>$ IDR. 400.000 s/d IDR. 800.000 \\
& $>$ IDR. 800.000 s/d IDR. 1.200.000 \\
& $>$ IDR. 1.200.000 s/d IDR. 2.000.000 \\
& $>$ Frequency of eating in a day \\
Basic Needs & $>$ Frequency of eating meat / milk / chicken once a week \\
& $>$ Ability to purchase or acquire clothing in a month / year \\
Asset Ownership & $>$ Productive asset ownership \\
Household Facilities and & $>$ Natural asset ownership \\
Infrastructure & $>$ Home ownership status \\
Access to Health Facilities & $>$ Conditions and availability of facilities in the house \\
& $>$ Health conditions of family members \\
Education & $>$ Availability and ease of obtaining health services \\
& $>$ Condition of education level of household members \\
& $>$ Availability and ease of use of educational services by \\
&
\end{tabular}

\section{RESULTS AND DISCUSSIONS}

\section{Results}

The data analysis tool (hypothesis) used in this study is the Paried Sample t-Test analysis. Testing this hypothesis, intends to see if there is a comparison of the welfare of the beneficiary community before and after the establishment of BUMDes Karya Dermawan. The results of testing this hypothesis, it can be seen in Table 2.

Tabel 2. Results of Hypothesis Testing Paired Sample t-Test

\begin{tabular}{cccc}
\hline Variable & $\mathbf{N}$ & t-Test & Sig. (2-tailed) \\
\hline Before - After & 60 & -71.269 & .000 \\
\hline
\end{tabular}

Table 2 shows the value of Sig. 2-tailed obtained 0.000. Because the value of Sig. 2-tailed is smaller than 0.05 , in accordance with the decision of hypothesis testing if the significant value of 2 -tailed $<0.05$ then $\mathrm{Ha}$ is accepted and $\mathrm{HO}$ is rejected. So, there are differences in community welfare before and after the establishment of BUMDes. The following will present the results of a descriptive test that was tested based on per-indicator of welfare so that the differences are clearly illustrated.

\section{Monthly Income Before and After BUMDes}

Monthly income of beneficiary community illustrates that there are differences before and after the establishment of BUMDes. It can be seen from the test results of the analysis descriptive in Table 3.

Tabel 3. Results of Descriptive Testing Monthly Income Before dan After BUMDes

\begin{tabular}{cccccc}
\hline & \multicolumn{5}{c}{ Income } \\
\cline { 2 - 6 } Variable & IDR. 400.000 & IDR. 800.000 & IDR. 1.200.000 & IDR. 2.000.000 \\
& s/d & s/d & s/d & s/d & Total \\
& IDR. 800.000 & IDR. 1.200.000 & IDR. 2.000.000 & IDR.5. 000.000 & \\
\hline Before & 22 & 24 & 8 & 6 & 60 \\
\hline After & 0 & 4 & 26 & 30 & 60 \\
\hline
\end{tabular}


Table 3 shows that from 60 respondents before BUMDes whose monthly income was IDR 400,000 - IDR 800,000 as many as 22 people, IDR 800,000 - IDR 1,200,000 as many as 24 people, IDR 1,200,000 IDR 2,000,000 as many as 8 people, and IDR 2,000,000 - IDR 5. 000000 as many as 6 people. Meanwhile, after the BUMDes changed, either IDR 400,000 - Rp. 800,000 as much as 0, IDR 800,000 - IDR 1,200,000 for 4 people, IDR 1,200,000 - IDR 2,000,000 as many as 26 people, and IDR 2,000,000 - IDR 5. 000000 as many as 30 people.

\section{Basic Needs Before and After BUMDes}

Basic needs of beneficiary community illustrate that there are differences before and after the establishment of BUMDes. It can be seen from the test results of the analysis descriptive in Table 4.

Tabel 4. Results of Descriptive Testing Basic Needs Before and After BUMDes

\begin{tabular}{ccc}
\hline Varieble & Average Value & Respondent \\
\hline Before & 7.05 & 60 \\
After & 8.38 & 60 \\
\hline
\end{tabular}

Table 4 (four) above shows that from 60 respondents the condition of basic needs befor BUMDes obtained an average value of 7.05, after BUMDes the average value increased by 8.38 .

\section{Asset Ownership Before and After BUMDes}

Asset Ownership of beneficiary community illustrates that there are differences before and after the establishment of BUMDes. It can be seen from the test results of the analysis descriptive in Table 5.

Tabel 5. Results of Descriptive Testing Asset Ownership Before and After BUMDes

\begin{tabular}{ccc}
\hline Varieble & Average Value & Respondent \\
\hline Before & 3.58 & 60 \\
After & 5.37 & 60 \\
\hline
\end{tabular}

Table 5 shows that from 60 respondents the condition of asset ownership before BUMDes obtained an average value of 3.58, after BUMDes the average value increased by 5.37 .

\section{Household Facilities and Infrastructure Before and After BUMDes}

Household Facilities and Infrastructure of beneficiary community illustrates that there are differences before and after the establishment of BUMDes. It can be seen from the test results of the analysis descriptive in Table 6.

Tabel 6. Results of Descriptive Testing Household Facilities and Infrastructure Before and After BUMDes

\begin{tabular}{ccc}
\hline Varieble & Average Value & Respondent \\
\hline Before & 4.38 & 60 \\
After & 6.77 & 60 \\
\hline
\end{tabular}

Table 6 (six) shows that from 60 respondents the condition of household facilities and infrastructure before BUMDes obtained an average value of 4.38, after BUMDes the average value increased by 6.77 .

\section{Access to Health Facilities Before and After BUMDes}

Access to Health Facilities of beneficiary community illustrates that there are differences before and after the establishment of BUMDes. It can be seen from the test results of the analysis descriptive in Table 7.

Tabel 7. Results of Descriptive Testing Access to Health Facilities Before and After BUMDes

\begin{tabular}{ccc}
\hline Variable & Average Value & Respondent \\
\hline Before & 3.77 & 60 \\
After & 5.58 & 60 \\
\hline
\end{tabular}


Table 7 shows that from 60 respondents the condition of health facilities before BUMDes obtained an average value of 3,77, after BUMDes the average value increased by 5,58.

\section{Education Before and After BUMDes}

Education to Health Facilities of beneficiary community illustrates that there are differences before and after the establishment of BUMDes. It can be seen from the test results of the analysis descriptive in Table 8.

Tabel 8. Results of Descriptive Testing Education Before and After BUMDes

\begin{tabular}{ccc}
\hline Variable & Average Value & Respondent \\
\hline Before & 4.52 & 60 \\
After & 5.77 & 60 \\
\hline
\end{tabular}

Table 8 (eight) above shows that from 60 respondents the condition of education before BUMDes obtained an average value of 4.52, after BUMDes the average value increased by 5.77 .

\section{Discussion \\ Monthly Income of Beneficiary Community Before and After Establishment of BUMDes}

One of the benefits felt by the community from the existence of BUMDes is being able to increase people's income through businesses established by BUMDes, which is equity participation for community businesses (Asmarianti, 2019; Nurhasan \& Munawar, 2020;). The results of the analysis test show that the classification of monthly income indicators has increased after the establishment of BUMDes Karya Dermawan. This can be seen, before the BUMDes Karya Dermawan was established, there were still many beneficiaries with a monthly income of IDR 400,000 - IDR 800,000 as many as 22 people, and income of IDR p. 800,000 - IDR. 1,200,000 as many as 24 people. while the income of IDR 1,200,000 - IDR 2,000,000 only 8 people, and the monthly income of IDR 2,000,000 - IDR 5. 000000 only 6 people. After the establishment of BUMDes Karya Dermawan monthly income of IDR 400,000 - IDR 800,000 there are no longer beneficiary communities who have this sub monthly income. Likewise, the monthly income of IDR 800,000 - IDR 1,200,000 leaves only 4 people. In fact, the monthly income of the beneficiaries is between IDR 1,200,000 - IDR 2,000,000 as many as 26 people (before BUMDes only 8), and IDR 2,000,000 - IDR 5. 000000 as many as 30 people (before BUMDes only 6 people).

\section{Basic Needs of Beneficiary Communities Before and After Establishment of BUMDes}

The emergence of BUMDes in the village actually gave new air to improve the economic sector of the village community. Because BUMDes can establish businesses that are more oriented towards the future, such as opening up business- opportunities so as to deliver great benefits for the sustainability of rural communities in meeting their basic daily needs (Tama, 2013). The increase also occurred in the classification of basic needs indicators. Before the establishment of BUMDes Karya Dermawan, the average score was 7.05. After the establishment of BUMDes Karya- Dermawan the average score increased to 8.38. BUMDes Karya Dermawan owns the Alsintan business, which aims to open up opportunities for the community to work so that it can become an additional source of community income.

\section{Ownership of Beneficiary Community Assets Before and After Establishment of BUMDes}

From the analysis test results, there is also an increase in the classification of asset ownership indicators. Before to the establishment of BUMDes Karya Dermawan, the average score was 3.58. After the establishment of BUMDes Karya Dermawan, the average score increased to 5.37. BUMDes is very strategic in building businesses that are engaged in meeting the needs or ownership of community assets (Nugroho, 2015). A great opportunity for the community to increase their need or ownership of assets, even though the context of BUMDes in all villages in Indonesia has different businesses. In this case, BUMDes managers must open new business opportunities and attract people to work, but the community must also be more serious in working in utilizing businesses within the BUMDes that can encourage or increase income so that community needs are met (Kirowati \& Setia, 2018).

\section{Household Facilities and Infrastructure of Beneficiary Community Before and After BUMDes}

In the classification of household facilities and infrastructure indicators there is also an increase. This can be seen from the analysis results obtained, before the establishment of BUMDes Karya Dermawan obtained an average value of 4.38. After the establishment of BUMDes Karya Dermawan the average score increased to 6.77. Mr. DT, a beneficiary of BUMDes Karya Dermawan, revealed that he works as a rice 
farmer. Besides waiting for the results of rice harvesting, he is looking for another job by utilizing the BUMDes Alsintan business so that it can be an additional income for him. And the results of that income are used for family needs, both for daily needs and for the needs of home facilities. Indeed, BUMDes Karya Dermawan does not focus on increasing the need for household facilities and infrastructure, but by increasing their income by utilizing existing businesses, it is possible that infrastructure needs can be met. If the availability of community jobs through businesses within the BUMDes, it can actually increase people's income so that be a decision that the needs of the community are met at all times (Kusumasari, 2018). Thus, BUMDes has a fighting spirit to build and the right solutions deliver greater prosperity for rural communities (Cahyani et al, 2019).

\section{Access Health Facilities of Beneficiary Community Before and After BUMDes}

Continuing on the classification of indicators of access to health facilities, where the analysis test results obtained show an increase. Prior to the establishment of Karya Dermawan BUMDes, the average score was 3.77. After the establishment of BUMDes Karya Dermawan the average score increased to 5.58. The phenomenon in rural areas from the past until now, are that people work as farmers and the results of farming are not fully distributed evenly can increase their income so that they have difficulty meeting their needs, such as the ease of access to needs, medical facility. A great opportunity to solve the problem is to take advantage of the efforts of BUMDes which can boost up to increase income for the village community. Increased income so that people are no longer difficult to meet their needs, both material and non-material needs (Sujarweni, 2015). In BUMDes Karya Dermawan, the businesses established are not oriented towards meeting the needs of access to public health facilities. BUMDes Karya Dermawan business is more engaged in providing job opportunities and business capital to the beneficiary community. Finally, one of the offers from the BUMDes Karya Dermawan, by inviting him to work in the workshop business, was immediately responded to and he admitted that he felt lucky to be able to work and take advantage of this manufacturing business, because it has been able to help increase his income. With this income, he will use it for the health costs of his wife who is pregnant and for the process of giving birth later.

\section{Education of Beneficiary Community Before and After BUMDes}

Then the classification of education indicators also increased. Before to the establishment of Karya Dermawan BUMDes, the average score was 4.52. After the establishment of Karya Dermawan BUMDes, the average score increased to 5.77. It is the same as in the previous explanation, that BUMDes Karya Dermawan has not touched the realm of education, but BUMDes provides social assistance or scholarships for underprivileged children. The relevant parties, both the BUMDes manager, the village government and the BPD, provide support for the distribution of social assistance or scholarships. From there again BUMDes managers provide opportunities to improve community businesses, by being provided with capital through BUMDes savings and loan businesses which can directly increase income so that the community is assisted in financing their children's schools. Thus, it can be concluded that the increase in community welfare after the establishment of BUMDes is due to the efforts established by BUMDes. These efforts include Cooperative, Agricultural Machine Tool Services (Alsintan), and Workshops (Perbengkelan), these businesses are the most influential on the beneficiaries for improving the welfare of the beneficiary communities. Indeed, there are still many other businesses established by BUMDes Karya Dermawan, but they have not been able to boost it more sharply for the welfare of the beneficiary community, such as Distribution of Production Facilities (Penyaluran Sarana Produksi), Waste Banks (Bank Sampah). So the essence of the active BUMDes Karya Dermawan business above, assists in providing business capital assistance, social assistance, and expanding employment opportunities that have an effect on increasing income so that the needs of the beneficiary community can be achieved and their needs met.

\section{CONCLUSION}

Based on the above result, it appears that BUMDes Karya Dermawan provides welfare to the beneficiary community through the businesses that have been built, including cooperatives, agricultural machinery services (Alsintan), and workshops (perbengkelan). This business is a business that contributes the most to the beneficiary community, by providing job opportunities, business capital assistance, social assistance so that it directly touches or succeeds in improving the welfare of the beneficiary community after the establishment of BUMDes Karya Dermawan as evidenced by the results of the Paried Sample t-Test analysis tool. BUMDes Karya Dermawan really needs an intense concern for all elements and/or a further thought or research is needed to explore more deeply considering the many problems that have not been revealed. Dusun Dalam Village Governments and BUMDes Managers should involve the entire village community, especially for pre-prosperous and prosperous 1 (one) families, because of the visible treatment 
only half of the community takes advantage of it. This is certainly not in line with the main pillar of the establishment of BUMDes Karya Dermawan. Furthermore, the problem that needs to be explored and researched is how BUMDes can have good management, because it is appropriate for BUMDes to bemanaged with good management activities so that they will attract each other with the pace of its development to to improve the community welfare. Other problems need to be explored and researched on certain themes, related to how to assess the welfare of the community from an Islamic economic perspective, and implement BUMDes Karya Dermawan based on Islamic economics.

\section{REFERENCES}

Albert, M. \& R. H. (2017). Quiet Revolution in Welfare Economics. Princeton University Press. https://doi.org/10.1515/9781400887057.

Anggraeni, M. R. R. S. (2016). Peranan Badan Usaha Milik Desa (BUMDes) Pada Kesejahteraan Masyarakat Pedesaan Studi Pada Bumdes Di Gunung Kidul, Yogyakarta. MODUS: Journals, 28(2), 155-167. https://doi.org/10.24002/modus.v28i2.848.

Asmarianti, D. (2019). Peningkatan Pendapatan Masyarakat Melalui Usaha- Usaha Yang Dijalankan Badan Usaha Milik Desa (Bumdes) Sepenuh Hati Desa Loa Duri Ilir Kecamatan Loa Janan Kabupaten Kutai Kartanegara. EJournal Ilmu Pemerintahan, 7(3), 1416-1428.

Badan Pusat Statistik (BPS). (2015). Welfare Indicators 2015. Badan Pusat Statistik.

Bappenas. (2010). Evaluasi Pelayanan KB Bagi Masyarakat Miskin (Keluarga Prasejahtera/KPS dan Keluarga Sejahtera-I/KS-I). Bappenas.

Budiono, P. (2015). Implementasi Kebijakan Badan Usaha Milik Desa (Bumdes) Di Bojonegoro (Studi di Desa Ngringinrejo Kecamatan Kalitidu Dan Desa Kedungprimpen KecamatanKanor). Jurnal Politik Muda, 4(1), 116-125. http://repository.unair.ac.id/17573/.

Cahyani, E., Guspul, A., \& Wijayanti, R. (2019). Analisi Pengaruh Bumdes Dalam Menopang Kesejahteraan Masyarakat Kecamatan Kepil Kabupaten Wonosobo (Studi Empiris Pada Bumdes Silatri Indah Desa Beran Dan Bumdes Srikandi Desa Ropoh). JEBE: Journal of Economic, Business and Engineering, 1(1), 32-39. https://ojs.unsiq.ac.id/index.php/jebe/article/view/873.

Caya, M. F. N. \& E. R. (2019). Dampak Bumdes Terhadap Kesejahteraan Masyarakat Di Desa Aik Batu Buding, Kabupaten Belitung, Provinsi Bangka Belitung. JIKS: Jurnal Ilmu Kesejahteraan Sosial, 20(1), 1-12. https://doi.org/10.7454/jurnalkessos.v20i1.193.

Fahrudin, A. (2014). Pengantar Kesejahteran sosial. Rafika Aditama.

Hahnel, R. (2005). Economic Justice and Democracy: From Competition To Cooperation (1th ed). RoutledgeTaylor \& Francis Group. https://doi.org/10.4324/9780203952160.

Ife, J. \& F. T. (2008). Community Development: Alternatif Pengembangan Masyarakat Di Era Globalisasi (S. et al Manurung (ed.); 3rd ed.). Pustaka Pelajar.

Ikhwansyah, I. et al. (2020). An Empowerment Of A Village Economy: (BUMDES) in Indonesia. International Journal of Innovation, Creativity and Change, 12(8), 192-207.

Kirowati, D. \& L. dwi S. (2018). Pengembangan Desa Mandiri Melalui Bumdes Dalam Meningkatkan Kesejahteraan Masyarakat Desa (Studi Kasus: Desa Temboro Kecamatan Karas Kabupaten Magetan). Jurnal AKSI (Akuntansi Dan Sistem Informasi), 1(1), 15-22. https://doi.org/10.32486/aksi.v2i1.213.

Kusumasari, I. R. (2018). Kontribusi Dharma Pitaloka Meningkatkan Kesejahteraan Masyarakat (Studi Kasus BUMDes Di Desa Curah Cottok Kecamatan Kapongan). Cermin: Jurnal Penelitian, 2(2), 119135. https://doi.org/10.36841/cermin_unars.v2i2.235.

McCain, R. A. (2019). Welfare Economics: An Interpretive History (1th ed). Routledge Taylor \& Francis Group. Melatyugra, N. et al. (2020). Penyuluhan dan Konsultasi Aspek Hukum dan Regulasi Pengelolaan BUMDesa. Magistrorum Et Scholarium: Jurnal Pengabdian Masyarakat, 1(2), 215-224. https://doi.org/10.24246/jms.v1i22020p215-224.

Midgley, J. (1995). Social Development "The Developmental Perspective In Social Welfare." Sage Publications. Midgley, J. (1998). Social Welfare In Global Context. Sage Publications.

Midgley, J. \& M. H. (2011). Grassroots Social Security in Asia: Mutual Aid, Microinsurance and Social Welfare (1th ed). Routledge Taylor \& Francis Group.

Nugroho, D. A. (2015). Evaluasi Penerapan dan Dampak Program Badan Usaha Milik Desa (BUMDES) Terhadap Kesejahteraan Masyarakat Rumah Tangga Miskin (RTM) di Desa Babadan Kecamatan Karangrejo Kabupaten Tulungagung (Periode Mei 2014-April 2015). JESP: Jurnal Ekonomi Dan Studi Pembangunan, 7(2), 79-82. http://journal.um.ac.id/index.php/jesp/article/view/5339.

Nurhasan, J. A., \& Munawar, A. H. (2020). Efektivitas Peran Bumdes terhadap Peningkatan Pendapatan Masyarakat di Desa Panjalu. ANTARADHIN: Jurnal Ekonomi Syariah Kontemporer, 1(2), 89-99. 
http://jurnal.iailm.ac.id/index.php/antaradhin/article/view/266.

Nuryadi et al. (2017). Dasar-Dasar Statistik Penelitian. Gramasurya.

Prihatin, R. B. et al. (2018). BUMDes dan Kesejahteraan Masyarakat Desa (C. Nurhayati (ed.); 1th ed). Pusat Penelitian Badan Keahlian DPR RI.

Pusat Kajian Dinamika Sistem Pembangunan. (2007). Panduan Pendirian dan Pengelolaan Badan Usaha Milik Desa. Fakultas Ekonomi, Universitas Brawijaya.

Ridlwan, Z. (2013). Payung Hukum Pembentukan BUMDes. Fiat Justitia Jurnal Ilmu Hukum, 7(3), 355-371. https://doi.org/10.25041/fiatjustisia.v7no3.396.

Ridlwan, Z. (2014). Urgensi Badan Usaha Milik Desa (BUMDes) Dalam Pembangunan Perekonomian Desa. Fiat Justisia Jurnal Ilmu Hukum, 8(3), 424-440. https://doi.org/10.25041/fiatjustisia.v8no3.314.

Setyobakti, M. H. (2017). Identification Of Business Enterprises BUMDES Based On Social and Economic Aspect (Case Study at BUMDes Ijen Lestari Tamansari Village District of Banyuwangi). Jurnal Ilmiah Bidang Akuntansi Dan Manajemen (JEMA), 1(2), 102-103. http://repository.stiewidyagamalumajang.ac.id/id/eprint/754.

Sujarweni, V. W. (2015). Statiska Untuk Bisnis dan Ekonomi. Pustaka Baru Press.

Suyanto \& Bambang Pudjianto. (2015). Pemberdayaan Masyarakat Menuju Desa Sejahtera (Studi Kasus Di Kabupaten Sragen). Sosio Konsepsia; Jurnal Penelitian Dan Pengembangan Keseajhteraan Sosial, 5(1), 340-354. https://doi.org/10.33007/ska.v5i1.164.

Syawie, M. \& H. S. (2012). Kemiskinan Dan Kesejahteraan: Sebuah Kajian Konsep. Sosio Informa; Kajian Permasalahan Sosial Dan Usaha Kesejahteraan Sosial, 17(1), 29-35. https://doi.org/10.33007/inf.v17i1.65.

Winarti, S. E. et al. (2020). Pemberdayaan Kelompok Perempuan Menggunakan Badan Usaha Milik Desa Dalam Meningkatkan Pendapatan Masyarakat Desa. Sosio Konsepsia; Jurnal Penelitian Dan Pengembangan Keseajhteraan Sosial, 9(2), 171-184. https://doi.org/10.33007/ska.v9i2.1854.

Yusuf, A. M. (2005). Metodologi Penelitian: Dasar-Dasar Penyelidikan Ilmiah. UNP Press.

Zastrow, C. (1996). Introduction to Social Work and Social Welfare (6th ed). Brooks/Cole Publishing.

Zulkarnaen, R. M. (2016). Pengembangan Potensi Ekonomi Desa Melalui Badan Usaha Milik Desa (Bumdes) Pondok Salam Kabupaten Purwakarta. Dharmakarya: Jurnal Aplikasi Ipteks Untuk Masyarakat, 5(1), 1-4. http://journal.unpad.ac.id/dharmakarya/article/download/11430/5226. 